\title{
Increased Expression of Activation Markers on CD8 Lymphocytes in Children with Human Immunodeficiency Virus-1 Infection
}

\author{
MICHAEL SCHLESINGER, VICKI PETERS, JIAN DOND JIANG, JULIA P. ROBOZ, AND \\ J. GEORGE BEKESI \\ Ruttenberg Cancer Center, T. J. Martell Laboratory for Leukemia, Cancer and AIDS Research \\ [M.S., J.D.J., J.P.R., J.G.B.], Department of Pediatrics [V.P.], The Mount Sinai School of Medicine,
} New York, New York 10029

\begin{abstract}
The aims of the present study were to analyze the impact of perinatal human immunodeficiency virus (HIV)-1 infection on lymphocyte maturation in children, to determine the expression of activation markers on $\mathrm{CD} 8^{+}$cells, and to define predictors of survival in HIV-infected children. Seventy-one children presenting HIV-related symptoms were included in the study; 29 were less than 2 y old and 42 were 2 to 12 y of age. Results were compared with those obtained in normal children of a similar age. In HIV-infected children the proportion of $\mathrm{CD}^{+}$and $\mathrm{CD} 8^{+} \mathrm{CD} 45 \mathrm{RA}^{+}$cells was significantly decreased, whereas that of $\mathrm{CD} 8^{+}, \mathrm{CD} 8^{+} \mathrm{CD} 38^{+}$, and $\mathrm{CD} 8^{+} \mathrm{CD} 45 \mathrm{RO}^{+}$cells was strikingly increased compared with controls. In children less than 2 y old the absolute number of $\mathrm{CD}^{+}$and $\mathrm{CD}^{+} \mathrm{CD}^{+} 5 \mathrm{RA}^{+}$cells decreased, and the number of $\mathrm{CD} 8{ }^{+} \mathrm{CD} 45 \mathrm{RO}^{+}$cells increased significantly, whereas the number of $\mathrm{CD}^{+}$and $\mathrm{CD} 8^{+} \mathrm{CD} 38^{+}$ cells did not change. The absolute number of $\mathrm{CD}^{+} \mathrm{T}$ cells declined with age both among controls and among HIV-infected
\end{abstract}

ABSTRACT
Only a relatively small fraction of the offspring of HIV-1infected mothers become infected by the virus $(1,2)$. Among the maternal factors which determine transmission of HIV-1 to the fetus are elevated p-24 antigenemia (2) and absence of high affinity antibodies to the neutralizing domain of gp120 (3). Neonates and young children seem to be relatively resistant to HIV infection and to progression of HIV disease, although it is not clear as yet what factors are involved. Among HIV-1infected hemophilic patients the rate of progression to AIDS is much lower in children less than 13 y old than in adults $(4,5)$. The lower rate of development of AIDS in HIV-1-infected children compared with infected adults may be associated with differences in lymphocyte populations (5). An age-dependent

Reccived February 28, 1994; accepted February 21, 1995

Correspondence and reprint requests: Prof. Michael Schlesinger, The Hubert H. Humphrey Conter for Expcrimental Mcdicine and Cancer Research, The Hebrew UniversityHadassah Medical School, Jerusalem, 91120, Israel.

Supported by National Institutes of Health-NIAID Grant IUOI-AI 27667 and by the T. J. Martel Foundation for Leukemia, Cancer and AIDS Research. children. In contrast, the absolute number of $\mathrm{CD} 8^{+}$cells and CD8 subsets decreased with age only in controls but not in infected children. In HIV-1-infected children the expression of the CD38 and CD45RO markers on $\mathrm{CD} 8^{+}$cells was significantly correlated, indicating that these were activated cells. The survival of less than 2-y-old children with AIDS symptoms was positively correlated with the total number of $\mathrm{CD} 8$ cells and $\mathrm{CD} 8^{+} \mathrm{CD} 38^{+}$ cells at time of entry into the study. Most of the children who died by the end of the study had a CD8 count of less than $750 / \mathrm{mm}^{3}$ and a $\mathrm{CD} 38^{+} \mathrm{CD} 8^{+}$count of less than $600 / \mathrm{mm}^{3}$ when first seen, whereas most of those who were alive had higher counts. (Pediatr Res 38: 390-396, 1995)

\section{Abbreviations \\ HIV, human immunodeficiency virus PBL, peripheral blood lymphocytes NK, natural killer}

cofactor or immune alteration in children may either control viral replication or limit its damage in the later phase of HIV disease (4).

In addition to marked impairment of the $\mathrm{CD}^{+} \mathrm{T}$ cell population, in HIV-1-infected adults alterations occur in other lymphocyte subsets and in the serum levels of soluble immune activation products $(6,7)$. $\mathrm{CD}^{+}$cells seem to be vital for suppression of the replication of HIV-1 (8). After HIV-1 infection the proportion of CD8 cells among PBL increases, and these cells show signs of activation, such as enhanced expression of CD38 (9-12) and elevated serum levels of soluble CD8 molecules $(6,7)$. The majority of $\mathrm{CD}^{+}$cells in HIV-infected adults display the CD45RO antigen (13), the expression of which is enhanced in $\mathrm{T}$ cells after activation, concomitantly with diminished expression of CD45RA (14). The CD45RA marker is typical for "naive" lymphocytes whereas the CD45RO marker is typical for "memory" cells (15). Among $\mathrm{CD}^{+}$lymphocytes the $\mathrm{CD}^{+} 5 \mathrm{RA}^{+}$cells induce 
immune suppression, whereas $\mathrm{CD} 45 \mathrm{RO}^{+}$cells function as helper-inducers $(15,16)$.

A number of studies have addressed the changes taking place in the immune system of children infected perinatally with HIV-1 (17-20). In previous studies of this laboratory various aspects of activation of the $\mathrm{CD}^{+} \mathrm{T}$ cell population were studied in adult HIV-infected individuals $(10,11,13)$. The aim of the present study was to analyze the lymphocyte phenotypes of children with perinatally acquired HIV-1 infection who varied in the time of appearance of AIDS-related clinical symptoms. The expression of activation markers on $\mathrm{CD}^{+}$cells of $\mathrm{HIV}$-infected children was determined and the role of these cells in HIV disease progression was assessed.

\section{METHODS}

Study population. The subjects in this study included 71 HIV seropositive $\left(\mathrm{HIV}^{+}\right)$children seen at the pediatric infectious disease clinics of the Mount Sinai Medical Center and of the Beth Israel hospital, New York City. Of these, 29 HIVinfected children were less than 2 y old, and 42 children were 2 to $12 \mathrm{y}$ of age. With the exception of three children who were infected by neonatal blood transfusion, the children were infected perinatally by their $\mathrm{HIV}^{+}$mother. All of the children in the study had AIDS-related symptoms at the time of their first visit in the clinic. Clinical evaluation of the $\mathrm{HIV}^{+}$children was according to the guidelines of the Center for Disease Control. Blood was obtained from all of the HIV-infected individuals at the time of their first visit. For each of the children in the study the presence of HIV-1 antibodies was determined by an ELISA and by HIV-1 demonstration in viral cultures. HIV-1 infection was confirmed by Western blot analysis. In addition, blood was obtained from a group of 41 healthy control children of ages similar to those of the HIV-infected children. The controls consisted of children with various noninfectious conditions seen at the pediatric outpatient clinic of the Mount Sinai Medical Center. The time of follow-up between the first visit of the children in the Clinic and definition of whether they were alive or dead at the end of the study was $3 \mathrm{y}$.

This study was carried out in adherence to guidelines of human experimentation as set forth by the Mount Sinai Medical Center, New York City and State, and the U.S. Department of Health and Human Services.

Immunophenotyping of lymphocyte subsets. Peripheral blood was taken by venipuncture from each subject using vacuum tubes with preservative-free heparin. Immunofluorescent staining was carried out by the whole blood technique, in which $150 \mu \mathrm{L}$ of blood were incubated with $20 \mu \mathrm{L}$ of specific pairs of MAb for $20 \mathrm{~min}$ at $25^{\circ} \mathrm{C}$ followed by the addition of $2 \mathrm{~mL}$ of fluorescene-activated cell sorter lysing solution (Becton Dickinson Immunocytometry Systems) and further incubation for $10 \mathrm{~min}$ at $25^{\circ} \mathrm{C}$. Cells were washed twice with $0.01 \mathrm{M}$ phosphate buffer in $0.85 \%$ saline (PBS) and fixed in $1 \%$ paraformaldehyde in PBS, pH 7.4. The MAb used were FITCconjugated $\mathrm{MAb}$ against CD45, CD3, CD4, CD8, CD19, and CD45RA, and phycoerythrin-conjugated antibodies against CD8, CD14, CD16, CD38, CD56, and CD45RO. All the conjugated $\mathrm{MAb}$ were obtained from Becton Dickinson Im- munocytometry Systems, San Jose, CA. Flow cytometric analysis was performed, as was described previously $(10,11)$ using a FACStar flow cytometer (Becton Dickinson Immunocytometry Systems) calibrated with CaliBrite beads and glutaraldehyde-fixed chicken red blood cells. Simulset software was used for the exclusion of dead cells, platelets, erythrocytes and granulocytes. The dual parameter contour program was used for analysis. In accordance with National Institutes of Health guidelines for flow cytometric immunophenotyping (20), the level of $\mathrm{CD} 4$ and $\mathrm{CD}^{+} \mathrm{T}$ cells was assessed by determining the proportion of cells that were either $\mathrm{CD} 3^{+} \mathrm{CD} 4^{+}$or $\mathrm{CD}^{+}{ }^{+} \mathrm{CD} 8^{+}$double positive. The level of NK cells was assessed by determining the proportion of cells that reacted with a mixture of phycoerythrin-labeled MAb against CD16 and CD56, but failed to react with FITC-labeled MAb against CD3.

Statistical analysis. The significance of differences of mean results in different groups was evaluated using a $t$ test. Regression analyses were computed in STAVEIW-II of Macintosh to explore the association between parameters. The significance of differences in proportions between groups was evaluated either by the $\chi^{2}$ test or by Fisher's exact probabilities, by using the software of Epidemiology Information Version 5.01 which was recommended by the Communicable Disease Center and World Health Organization Global Program on AIDS.

\section{RESULTS}

Lymphocyte subsets in AIDS patients less than 2 y old. The lymphocyte populations in HIV-infected children who were less than 2 y old when first seen in the clinic were compared with those found in control children of similar age. In children less than $2 \mathrm{y}$ old, the percentage and absolute number of lymphocytes was not significantly different between controls and HIV-infected children (Tables 1 and 2). There were no differences in the proportion (Table 1) and absolute number (Table 2) of B-lymphocytes (CD19 ${ }^{+}$cells) and in the absolute number of $\mathrm{NK}$ cells (CD16 ${ }^{+}$and $\mathrm{CD} 56^{+}$cells) between the two groups of children. The proportion of T-lymphocytes $\left(\mathrm{CD}^{+}\right.$cells) was slightly lower among HIV-infected children than among controls, whereas the absolute $\mathrm{T}$ cell number was significantly decreased $(p=0.03)$. The level of $\mathrm{CD}^{+}$cells was significantly lower among HIV-infected children than among controls in terms of their percentage $(p=0.0001)$ and their absolute number $(p=0.0008)$. The proportion of $\mathrm{CD} 8^{+}$ cells was higher among HIV-infected children than among controls ( $p=0.0003$ ), although their absolute number did not differ significantly. The expression of two activation markers on $\mathrm{CD}^{+}$lymphocytes was assessed. The proportion of $\mathrm{CD} 8{ }^{+} \mathrm{CD} 38^{+}$cells was higher in HIV-infected children less than $2 \mathrm{y}$ of age than in healthy controls $(p=0.02)$. The absolute number of $\mathrm{CD} 8^{+} \mathrm{CD} 38^{+}$cells was, however, similar in the two groups of children. The data shown in Tables 1 and 2 indicate that in both the infected and the control group the majority of the $\mathrm{CD}^{+}$cells displayed the CD38 antigen. Among young HIV-infected children the percentage of $\mathrm{CD} 8^{+} \mathrm{CD} 45 \mathrm{RO}^{+}$cells was strikingly higher than in normal controls $(p=0.0001)$, whereas that of $\mathrm{CD}^{+} 45 \mathrm{RA}^{+}$was reduced $(p=0.008)$. The number of $\mathrm{CD} 8^{+}$cells expressing 
Table 1. The proportion of PBL expressing various surface markers among normal and HIV-infected children

\begin{tabular}{|c|c|c|c|c|c|c|}
\hline \multirow[b]{2}{*}{ Phenotype } & \multicolumn{3}{|c|}{ Less than 2-y-old children } & \multicolumn{3}{|c|}{ 2- to 12 -y-old children } \\
\hline & $\begin{array}{c}\text { Controls } \\
\text { (23) }\end{array}$ & $\begin{array}{l}\text { HIV-infected } \\
\text { (29) }\end{array}$ & $p^{*}$ & $\begin{array}{c}\text { Control } \\
(18)\end{array}$ & $\begin{array}{c}\text { HIV-infected } \\
(42)\end{array}$ & $p^{*}$ \\
\hline Lymphocytes (\%) & $58 \pm 13 \dagger$ & $51 \pm 18$ & NS & $31 \pm 7$ & $44 \pm 17$ & 0.003 \\
\hline $\mathrm{CD}^{+}$ & $66 \pm 7$ & $61 \pm 13$ & NS & $70 \pm 9$ & $70 \pm 16$ & NS \\
\hline $\mathrm{CD}^{+} \mathrm{CD}^{+}$ & $44 \pm 8$ & $25 \pm 15$ & 0.0001 & $39 \pm 8$ & $20 \pm 12$ & 0.0001 \\
\hline $\mathrm{CD}^{+} \mathrm{CDD}^{+}$ & $22 \pm 5$ & $35 \pm 15$ & 0.0003 & $29 \pm 5$ & $47 \pm 15$ & 0.0001 \\
\hline $\mathrm{CD} 16^{+}, \mathrm{CD} 56^{+}$ & $13 \pm 7$ & $17 \pm 7$ & 0.04 & $14 \pm 8$ & $18 \pm 14$ & NS \\
\hline $\mathrm{CD} 19^{+}$ & $22 \pm 8$ & $21 \pm 11$ & NS & $19 \pm 5$ & $17 \pm 7$ & NS \\
\hline $\mathrm{CD} 8^{+} \mathrm{CD} 38^{+}$ & $20 \pm 7$ & $29 \pm 15$ & 0.02 & $24 \pm 7$ & $40 \pm 17$ & 0.0003 \\
\hline $\mathrm{CD}^{+} \mathrm{CD} 45 \mathrm{RO}^{+}$ & $12 \pm 7$ & $36 \pm 21$ & 0.0001 & $10 \pm 1$ & $46 \pm 20$ & 0.0001 \\
\hline $\mathrm{CD}^{+} \mathrm{CD}^{2} 5 \mathrm{RA}^{+}$ & $17 \pm 7$ & $12 \pm 3$ & 0.008 & $25 \pm 7$ & $12 \pm 3$ & 0.0001 \\
\hline
\end{tabular}

* Significance of difference between results in normal and in HIV-infected children of similar age group. NS = not significant.

$\dagger$ Mean \pm SD.

Table 2. The absolute number of PBL expressing various surface markers among normal and HIV-infected children

\begin{tabular}{|c|c|c|c|c|c|c|}
\hline \multirow[b]{2}{*}{ Phenotype } & \multicolumn{3}{|c|}{ Less than 2-y-old children } & \multicolumn{3}{|c|}{2 - to 12 -y-old children } \\
\hline & $\begin{array}{c}\text { Controls } \\
\text { (23) }\end{array}$ & $\begin{array}{l}\text { HIV-infected } \\
(29)\end{array}$ & $p^{*}$ & $\begin{array}{c}\text { Controls } \\
\text { (18) }\end{array}$ & $\begin{array}{l}\text { HIV-infected } \\
\quad(42)\end{array}$ & $p^{*}$ \\
\hline Lymphocyte (no./mm $\mathrm{mm}^{3}$ ) & $5734 \pm 2005 \dagger$ & $4497 \pm 2466$ & NS & $2401 \pm 777$ & $2932 \pm 1955$ & NS \\
\hline $\mathrm{CD}^{+}$ & $3816 \pm 1378$ & $2787 \pm 1694$ & 0.03 & $1641 \pm 467$ & $2161 \pm 1590$ & NS \\
\hline $\mathrm{CD}{ }^{+} \mathrm{CD}_{3}{ }^{+}$ & $2495 \pm 961$ & $1415 \pm 1138$ & 0.0008 & $904 \pm 235$ & $597 \pm 463$ & 0.01 \\
\hline $\mathrm{CD} 8^{+} \mathrm{CD} 3^{+}$ & $1260 \pm 523$ & $1432 \pm 922$ & NS & $687 \pm 266$ & $1476 \pm 1295$ & 0.01 \\
\hline $\mathrm{CD} 16^{+}, \mathrm{CD} 56^{+}$ & $735 \pm 470$ & $736 \pm 512$ & NS & $360 \pm 246$ & $478 \pm 519$ & NS \\
\hline $\mathrm{CD} 19^{+}$ & $1230 \pm 676$ & $941 \pm 544$ & NS & $465 \pm 236$ & $490 \pm 435$ & NS \\
\hline $\mathrm{CD} 8^{+} \mathrm{CD} 38^{+}$ & $1147 \pm 527$ & $1098 \pm 825$ & NS & $590 \pm 267$ & $1260 \pm 1151$ & 0.02 \\
\hline $\mathrm{CD} 8{ }^{+} \mathrm{CD} 45 \mathrm{RO}^{+}$ & $739 \pm 526$ & $1323 \pm 959$ & 0.01 & $229 \pm 106$ & $1479 \pm 1408$ & 0.009 \\
\hline $\mathrm{CD}^{+} \mathrm{CD} 45 \mathrm{RA}^{+}$ & $1043 \pm 436$ & $591 \pm 368$ & 0.001 & $505 \pm 237$ & $379 \pm 262$ & NS \\
\hline
\end{tabular}

* Significance of difference between results in normal and in HIV-infected children of similar age group. NS = not significant.

$\uparrow$ Mean \pm SD.

the CD45RO activation marker was, likewise, higher than in the normal controls $(p=0.01)$, whereas the number of $\mathrm{CD}^{+} \mathrm{CD}^{2} 5 \mathrm{RA}^{+}$cells was markedly lower $(p=0.001)$. The results shown in Tables 1 and 2 indicate that, although CD45RO was present on about half of the $\mathrm{CD} 8^{+}$cells in the controls, this marker was expressed on all of the CD8 cells in HIV-infected children. Conversely, the CD45RA marker was present on the majority of $\mathrm{CD} 8^{+}$cells in normal controls but only on less than half of the $\mathrm{CD}^{+}$cells in HIV-infected children.

Lymphocyte subsets in 2- to 12-y-old AIDS patients. The proportion of lymphocytes was higher among HIV-infected 2to 12 -y-old children than among controls (Table $1, p=0.003$ ). The proportion of $T$ cell subsets in 2- to 12-y-old HIV-infected children differed markedly from that found in controls of similar age (Table 1$)$. The percentage of $\mathrm{CD}^{+}$cells was strikingly decreased $(p=0.0001)$, whereas that of $\mathrm{CD} 8^{+}$cells was increased $(p=0.0001)$. The proportion of $\mathrm{CD} 8^{+} \mathrm{CD} 38^{+}$ cells and of $\mathrm{CD}^{+} \mathrm{CD} 45 \mathrm{RO}^{+}$cells was significantly higher in HIV-1-infected children than in controls $(p=0.0003$ and 0.0001 , respectively), whereas that of $\mathrm{CD} 8{ }^{+} \mathrm{CD} 45 \mathrm{RA}^{+}$cells was lower $(p=0.0001)$. The majority of $\mathrm{CD}^{+}$cells expressed CD38 both in infected and in normal children. All of the CD8 cells in infected children expressed CD45RO, whereas in healthy controls the majority of the CD8 cells expressed CD45RA. There were no significant differences between controls and AIDS patients in the percentage of total $\mathrm{T}, \mathrm{B}$, or NK cells.
The lymphocyte count among 2- to 12-y-old HIV-infected children was nonsignificantly higher than in controls (Table 2). The mean number of total T, B, and NK cells was slightly higher in HIV-infected children than in controls. The number of $\mathrm{CD}^{+}$cells was lower than in controls $(p=0.01)$. In contrast, the population of $\mathrm{CD} 8^{+}$cells was expanded in HIVinfected children $(p=0.01)$ and so were the populations of $\mathrm{CD} 8{ }^{+} \mathrm{CD} 45 \mathrm{RO}^{+}$and $\mathrm{CD} 8{ }^{+} \mathrm{CD} 38^{+}$cells $(p=0.009$, and 0.02 , respectively).

Correlation of age with the level of lymphocyte populations. Marked changes occur in the lymphocyte system in children during their normal development (21-25). In the present study the absolute number of various lymphocyte subsets in controls and in children with AIDS was correlated with their age, expressed on a log scale.

In control children the decline of the absolute number of lymphocytes closely correlated with age (Fig. $1 A, r=0.85, p$ $=0.0001)$. An age-related decline of the lymphocyte number was also detectable among HIV-infected children, in spite of a larger variation than among controls (Fig. 1A) $(r=0.33, p=$ $0.006)$. The decline of the absolute number of $\mathrm{CD}^{+} \mathrm{T}$ cells among controls was significantly correlated with age (Fig. $1 A$, $r=0.83, p=0.0001)$. An age-related decline of $\mathrm{CD}^{+} \mathrm{T}$ cells was also seen among HIV-infected children (Fig. $1 A, r=0.32$, $p=0.008$ ). The lower $r$ values in the infected group reflected a larger variation of the results among infected than among control children. The curve fit for the number of $\mathrm{CD} 4{ }^{+}$cells in controls was $y=-0.4358(\log x)+1750$, whereas that for 


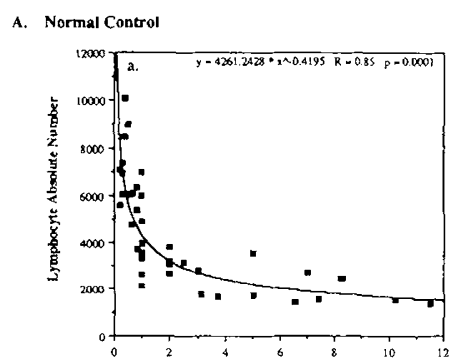

HIV-1 Infected
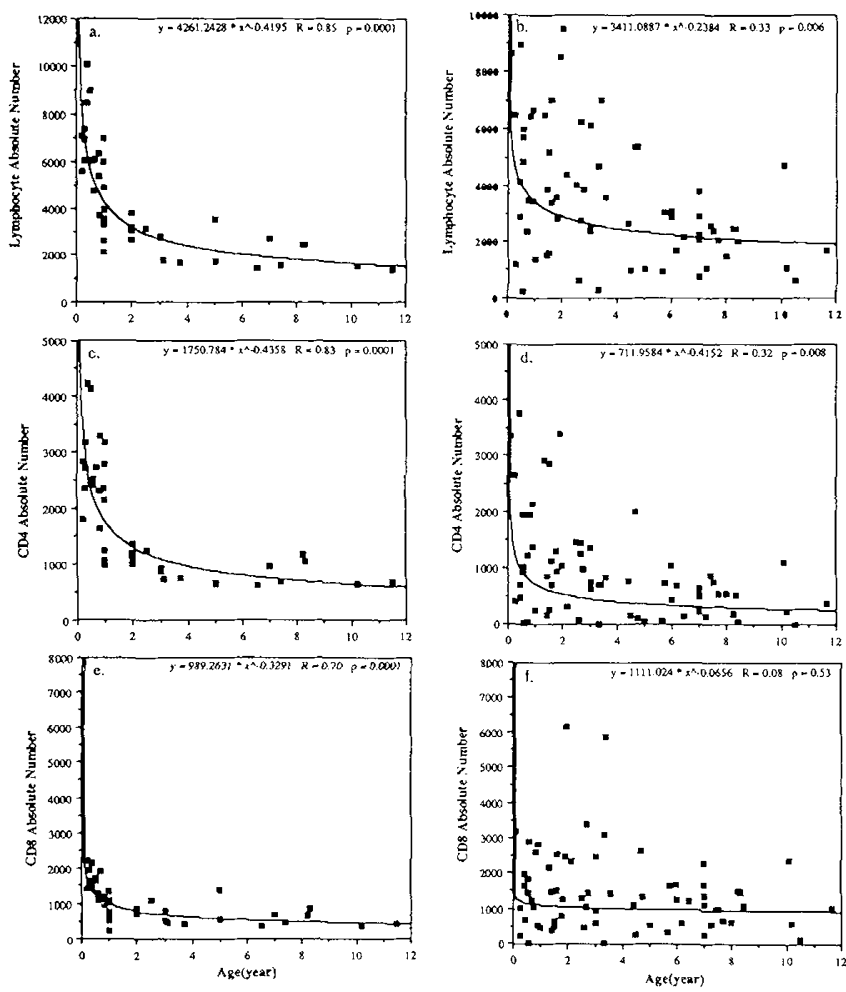

B. Normal Control
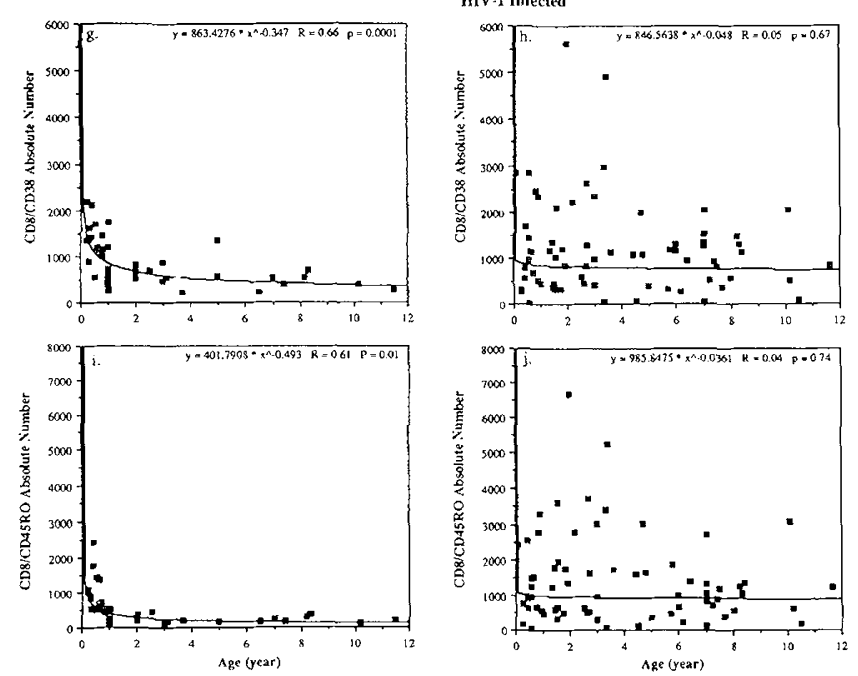

Figure 1. Correlation between age and the absolute numbers of various lymphocyte subsets in normal controls and in HIV-1-infected children. The absolute number of lymphocytes (per $\mathrm{mm}^{3}$ ) of various subsets on a log scale is correlated with age ( 0 to $12 \mathrm{y})$ on an arithmetic scale. The left column depicts correlations obtained with the normal controls, whereas the right column depicts correlations obtained with the HIV-infected children. Correlation with age is shown for the following parameters: $(A)$ (from top to bottom) 1) total number of lymphocytes, 2) number of $\mathrm{CD} 4^{+}$cells, and 3) number of $\mathrm{CD} 8^{+}$cells. $(B)$ 1) number of $\mathrm{CD} 8^{+} \mathrm{CD} 38^{+}$cells and 2) number of $\mathrm{CD}^{+} \mathrm{CD}^{+} 5 \mathrm{RO}^{+}$cells

HIV-infected children was $y=-0.4152(\log x)+712$. Thus for each age the average number of $\mathrm{CD}^{+}$cells among HIVinfected children was less than half of that found among controls of similar age. Moreover, the rate of decline of the number of $\mathrm{CD}^{+}$cells with age was similar in HIV-infected and control children.
The proportion of $\mathrm{CD}^{+}$cells increased significantly with age in both controls $(r=0.4, p=0.003)$ and in HIV-infected children ( $r=0.3, p=0.005$, not shown). Among controls the absolute number of $\mathrm{CD}^{+} \mathrm{T}$ cells was clearly seen to decrease with age. A striking correlation with age was noted in the controls not only for the total number of $\mathrm{CD}^{+}$cells (Fig. $1 \mathrm{~A}$, $r=0.70, p=0.0001)$ but also for the number of $\mathrm{CD} 8^{+} \mathrm{CD} 38^{+}$ $(r=0.66, p=0.0001)$ (Fig. $1 B)$ and $\mathrm{CD}^{+} \mathrm{CD}^{+} 5 \mathrm{RO}^{+}$cells $(r$ $=0.61, p=0.01$ ) (Fig. $1 B$ ). In contrast, in HIV-infected children no correlation between age and the absolute number of either $\mathrm{CD} 8{ }^{+}, \mathrm{CD} 8{ }^{+} \mathrm{CD} 38^{+}$, or $\mathrm{CD} 8^{+} \mathrm{CD} 45 \mathrm{RO}^{+}$cells could be seen (Fig. 1B).

Correlation between various lymphocyte subsets. A strong correlation was noted between the expression of the CD38 and CD45RO markers on $\mathrm{CD}^{+}$cells in individual HIV-infected children. The proportions of $\mathrm{CD} 8^{+} \mathrm{CD} 38^{+}$and of $\mathrm{CD}^{+} \mathrm{CD}^{2} 5 \mathrm{RO}^{+}$lymphocytes were closely correlated $(r=$ $0.9, p<0.0001$ ) (Fig. 2A), as were the absolute numbers of $\mathrm{CD}^{+} \mathrm{CD} 38^{+}$and of $\mathrm{CD} 8^{+} \mathrm{CD} 45 \mathrm{RO}^{+}$cells $(r=0.9, p<$ $0.0001)$. The same strong correlation between expression of $\mathrm{CD} 38$ and expression of $\mathrm{CD} 45 \mathrm{RO}$ on $\mathrm{CD}^{+}$cells was also seen when HIV-infected children who were either younger than $2 \mathrm{y}$ of age or older were analyzed separately (not shown). In contrast to the results obtained with HIV-infected children, no correlation was found between the proportion of CD8 cells expressing the CD38 and CD45RO markers in controls (not shown). No correlation was seen between the proportion of $\mathrm{CD}^{+} \mathrm{CD} 8^{+}$cells and the proportion of $\mathrm{CD}^{+} \mathrm{CD} 45 \mathrm{RA}^{+}$ cells either among HIV-infected children (Fig. $2 B$ ) or among control children. A strong inverse correlation was noted between the percentage of $\mathrm{CD}^{+}, \mathrm{CD}^{+} \mathrm{CD} 38^{+}$(Fig. 2C) or $\mathrm{CD}^{+} \mathrm{CD}^{+} 5 \mathrm{RO}^{+}$cells, and the percentage of $\mathrm{CD}^{+}$cells $(r=$
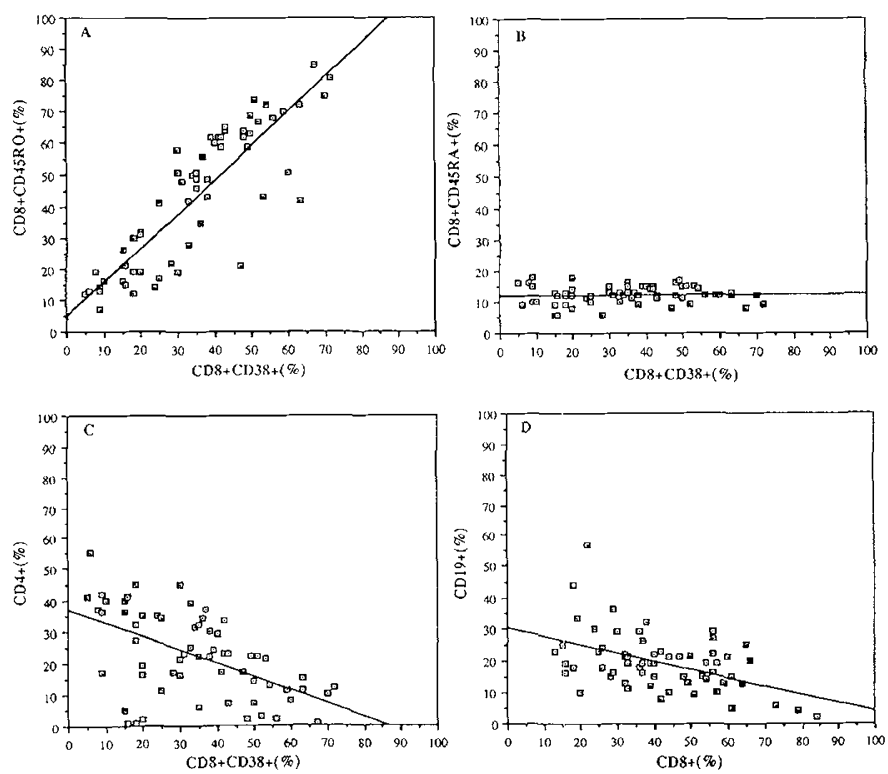

Figure 2. Correlation between various phenotypic markers in HIV-1-infected children. (A) Correlation between the proportion of $\mathrm{CD}^{+} \mathrm{CD}^{+} 5 \mathrm{RO}^{+}$and $\mathrm{CD} 8^{+} \mathrm{CD} 38^{+}$cells. $(B)$ Correlation between the proportion of $\mathrm{CD} 8^{+} \mathrm{CD} 45 \mathrm{RA}^{+}$ and $\mathrm{CD} 8^{+} \mathrm{CD} 38^{+}$cells. $(C)$ Correlation between the proportion of $\mathrm{CD} 8^{+} \mathrm{CD} 38^{+}$and $\mathrm{CD} 4^{+}$cells. $(D)$ Correlation between the proportion of $\mathrm{CD} 8^{+}$and $\mathrm{CD} 19^{-1}$ cells. 
$-0.4, p=0.0002, r=-0.6, p=0.0001, r=-0.6, p=$ 0.0001 , respectively). There also was a striking inverse correlation between the proportion of $\mathrm{CD} 8^{+}$(Fig. $2 D$ ), $\mathrm{CD} 8^{+} 38^{+}$ and $\mathrm{CD} 8^{+} \mathrm{CD} 45 \mathrm{RO}^{+}$cells and the proportion of $\mathrm{CD} 19^{+}$cells $\left(r=-0.5 p=0.0001\right.$ for correlation with $\mathrm{CD}^{+}$cells, and $r$ $=-0.4, p=0.005$ for correlation with either $\mathrm{CD} 8{ }^{+} \mathrm{CD} 38^{+}$or $\mathrm{CD} 8^{+} \mathrm{CD} 45 \mathrm{RO}^{+}$cells).

Correlation between initial phenotype and clinical course. The phenotype of HIV-infected children, determined during their first visit, was correlated with their subsequent clinical course. The number of lymphocytes in various subsets and the survival of the children were correlated separately for HIVinfected children of the two age groups studied (Table 3). In children below the age of $2 \mathrm{y}$ there was a strong correlation between low counts of $\mathrm{CD}^{+}$cells $\left(<500 / \mathrm{mm}^{3}\right)$ at the time of the first visit and mortality by the end of the study ( $p<$ $0.00005)$. In children less than $2 \mathrm{y}$ old there also was a significant correlation between mortality and low counts of

Table 3. Correlation of lymphocyte counts at first visit and survival

\begin{tabular}{|c|c|c|c|c|c|}
\hline \multirow{2}{*}{$\begin{array}{l}\text { Age at first visit } \\
(y)\end{array}$} & \multirow[b]{2}{*}{ Marker tested } & \multicolumn{3}{|c|}{$\begin{array}{c}\text { Individuals with } \\
\text { marker who at end of } \\
\text { study were: }\end{array}$} & \multirow{2}{*}{$\begin{array}{c}\text { Significance } \\
\text { of } \\
\text { difference* }\end{array}$} \\
\hline & & Alive & Dead & Total & \\
\hline \multirow[t]{12}{*}{$\leq 2(n=21)$} & $\mathrm{CD}^{+}$ & & & & \\
\hline & $<500 / \mathrm{mm}^{3}$ & 0 & 5 & 5 & 0.00005 \\
\hline & $\geq 500 / \mathrm{mm}^{3}$ & 16 & 0 & 16 & \\
\hline & $\mathrm{CD}^{+}{ }^{+}$ & & & & \\
\hline & $<750 / \mathrm{mm}^{3}$ & 2 & 4 & 6 & 0.01 \\
\hline & $\geq 750 / \mathrm{mm}^{3}$ & 14 & 1 & 15 & \\
\hline & $\mathrm{CD} 8^{+} \mathrm{CD} 38^{+}$ & & & & \\
\hline & $<600 / \mathrm{mm}^{3}$ & 4 & 4 & 8 & 0.04 \\
\hline & $\geq 600 / \mathrm{mm}^{3}$ & 12 & 1 & 13 & \\
\hline & 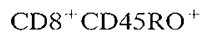 & & & & \\
\hline & $<650 / \mathrm{mm}^{3}$ & 3 & 3 & 6 & 0.1 \\
\hline & $\geq 650 / \mathrm{mm}^{3}$ & 13 & 2 & 15 & \\
\hline \multirow[t]{12}{*}{$>2(n=29)$} & $\mathrm{CD} 4^{+}$ & & & & \\
\hline & $<500 / \mathrm{mm}^{3}$ & 6 & 7 & 13 & 0.009 \\
\hline & $\geq 500 / \mathrm{mm}^{3}$ & 15 & 1 & 16 & \\
\hline & $\mathrm{CD} 8^{+}$ & & & & \\
\hline & $<750 / \mathrm{mm}^{3}$ & 6 & 3 & 9 & 0.6 \\
\hline & $\geq 750 / \mathrm{mm}^{3}$ & 15 & 5 & 20 & \\
\hline & $\mathrm{CD} 8^{+} \mathrm{CD} 38^{+}$ & & & & \\
\hline & $<600 / \mathrm{mm}^{3}$ & 6 & 3 & 9 & 0.7 \\
\hline & $\geq 600 / \mathrm{mm}^{3}$ & 15 & 5 & 20 & \\
\hline & $\mathrm{CD}^{+}{ }^{+} \mathrm{CD} 45 \mathrm{RO}^{+}$ & & & & \\
\hline & $<650 / \mathrm{mm}^{3}$ & 7 & 3 & 10 & 1.0 \\
\hline & $\geq 650 / \mathrm{mm}^{3}$ & 14 & 5 & 19 & \\
\hline \multirow[t]{12}{*}{ All $(n=50)$} & $\mathrm{CD} 4^{+}$ & & & & \\
\hline & $<500 / \mathrm{mm}^{3}$ & 6 & 12 & 18 & 0.000002 \\
\hline & $\geq 500 / \mathrm{mm}^{3}$ & 31 & 1 & 32 & \\
\hline & $\mathrm{CD} 8^{+}$ & & & & \\
\hline & $<750 / \mathrm{mm}^{3}$ & 8 & 7 & 15 & 0.04 \\
\hline & $\geq 750 / \mathrm{mm}^{3}$ & 29 & 6 & 35 & \\
\hline & $\mathrm{CD} 8^{+} \mathrm{CD} 38^{+}$ & & & & \\
\hline & $<600 / \mathrm{mm}^{3}$ & 10 & 7 & 17 & 0.09 \\
\hline & $\geq 600 / \mathrm{mm}^{3}$ & 27 & 6 & 33 & \\
\hline & $\mathrm{CD}^{+}{ }^{+} \mathrm{CD} 45 \mathrm{RO}^{+}$ & & & & \\
\hline & $<650 / \mathrm{mm}^{3}$ & 10 & 6 & 16 & 0.3 \\
\hline & $\geq 650 / \mathrm{mm}^{3}$ & 27 & 7 & 34 & \\
\hline
\end{tabular}

* The significance of the differences was calculated with Fisher's exact probability test.
$\mathrm{CD} 8^{+}$cells $\left(<750 / \mathrm{mm}^{3}\right)(p=0.01)$ and of $\mathrm{CD} 8^{+} \mathrm{CD} 38^{+}$cells $\left(<600 / \mathrm{mm}^{3}\right)(p=0.04)$. The proportion of HIV-infected children with high counts of $\mathrm{CD} 8{ }^{+} \mathrm{CD}^{2} 45 \mathrm{RO}^{+}$cells $(>650 /$ $\mathrm{mm}^{3}$ ) was higher among the survivors. There was, however, no significant correlation between the counts of this subset and mortality.

Among 2- to 12-y-old children the only statistically significant difference seen between the phenotypes of those children that remained alive throughout the study and those who had died was the number of $\mathrm{CD}^{+}$cells at the first visit $(p=$ 0.009). Pooling of the results obtained in HIV-infected children of all ages indicated a highly significant association between survival and high counts of $\mathrm{CD} 4^{+}$cells, and to a lesser extent of $\mathrm{CD} 8^{+}$cells.

\section{DISCUSSION}

Striking changes of the total number of lymphocytes and of various lymphocyte subsets occur during normal differentiation of the lymphoid system in children (21-25). In the present study the impact of neonatal HIV infection on the development of lymphocyte subsets was studied. After perinatal HIV infection the level of $\mathrm{CD} 4$ lymphocytes was already reduced within the first $2 \mathrm{y}$ of life. The slope of the decline of the number of $\mathrm{CD} 4{ }^{+}$cells with age was, however, similar in HIV-infected and in control children. A comparable observation was made on the rate of decline of the proportion of $\mathrm{CD}^{+}$cells (19). Thus, the level of $\mathrm{CD}^{+}$cells in HIV-infected children is determined not only by viral infection but also by a differentiation process responsible for the age-related decline of the numer of $\mathrm{CD} 4$ cells. The proportion of $\mathrm{CD} 8^{+}$cells was elevated in HIV-infected children of all age groups studied. Although in controls the absolute number of $\mathrm{CD} 8^{+}$cells showed a strong negative correlation with age, no such a correlation was found in HIV-infected children. It became clear, therefore, that the level of $\mathrm{CD} 8^{+}$cells in infected children was predominantly determined by viral infection.

In normal adults the CD38 activation marker (26) is expressed only on a fraction of peripheral blood $\mathrm{CD}^{+}$cells, varying from 13 to $55 \%(7,11,27,28)$ of the CD8 population. In HIV-infected adults the proportion of $\mathrm{CD} 8^{+} \mathrm{CD} 38^{+}$cells rises early (10), and with progression of the disease into overt AIDS most CD 8 cells are $\mathrm{CD} 38^{+}(9-12,27,28)$. In normal cord blood (12) and in children less than 4 y old (19) the majority of the $\mathrm{CD} 8^{+}$lymphocytes express $\mathrm{CD} 38$. In the present study, $\mathrm{CD} 38$ was expressed on the majority of $\mathrm{CD} 8$ cells both in normal children and in HIV-infected children. In older HIV-infected children the proportion and number of $\mathrm{CD} 8^{+} \mathrm{CD} 38^{+}$cells was considerably increased.

Activation of $\mathrm{T}$ cells increases the expression of the CD45RO marker while diminishing that of CD45RA (14). The proportion of $\mathrm{CD}^{+}$or $\mathrm{CD} 8^{+}$cells which express $\mathrm{CD} 45 \mathrm{RO}$ increases in normal children with age (29). Similar to adult HIV-infected individuals (13), in seropositive children an increased proportion of $\mathrm{CD} 8$ cells are $\mathrm{CD} 45 \mathrm{RO}^{+}(18)$ and $\mathrm{CD} 4 \mathrm{RA}^{-}$(19). In HIV-infected children tested in the present study, practically all of the $\mathrm{CD} 8^{+}$cells were $\mathrm{CD} 45 \mathrm{RO}^{+}$, whereas the proportion of $\mathrm{CD}^{+}{ }^{+} \mathrm{CD} 45 \mathrm{RA}^{+}$was decreased. A 
considerable percentage of the CD8 cells displayed both CD45RA and CD45RO, indicating that they were in a transitional state. The proportion of $\mathrm{CD}^{+}{ }^{+}$cells expressing CD45RO was higher in the present study, in which all of the children tested had HIV-related symptoms, than in the study of Froebel et al. (18) in which most of the $\mathrm{HIV}^{+}$children were asymptomatic.

Many of the markers expressed on activated lymphocytes are also present on immature lymphocytes. CD45RO, a marker of activated or memory cells $(14,15)$, is present on immature, cortical thymocytes (14). Similarly, the CD38 marker which is displayed by the majority of human thymus cells (30), is an early T cell activation marker (26). $\mathrm{CD} 8^{+} \mathrm{CD} 38^{+} \mathrm{PBL}$ appearing after HIV infection could, therefore, constitute either activated $T$ cells or immature $T$ cells, released prematurely. In normal adults the expression of CD38 in circulating $\mathrm{T}$ cells is more closely associated with immaturity than with activation $(12,31)$. In contrast, $\mathrm{CD} 8^{+} \mathrm{CD} 38^{+}$cells in HIV-infected individuals seem to represent activated cells, because the cytotoxic $\mathrm{T}$ cell activity in HIV-infected adults is correlated with the proportion of $\mathrm{CD} 8^{+} \mathrm{CD} 38^{+}$cells $(32)$ and the $\mathrm{CD} 8^{+}$cells which exert the strongest HIV-specific cytotoxic activity express the $\mathrm{CD} 38$ antigen (33). In the present study the percentages of $\mathrm{CD} 8^{+} \mathrm{CD} 45 \mathrm{RO}^{+}$cells and of $\mathrm{CD} 8^{+} \mathrm{CD} 38^{+}$cells were strongly correlated among HIV-infected children but not among normal controls. Thus, in HIV-infected children $\mathrm{CD} 8^{+} \mathrm{CD} 38^{+}$cells co-express the $\mathrm{CD} 45 \mathrm{RO}$ marker and therefore probably constitute activated cells.

In adult HIV-infected individuals the most powerful prognostic indicators of disease progression were the percentage of $\mathrm{CD}^{+}$cells and the $\mathrm{CD} 4 / \mathrm{CD} 8$ ratio (6). In addition, a positive correlation was noted between the level of $\mathrm{CD} 8^{+} \mathrm{CD} 38^{+}$cells in HIV-infected adults at the time of the first test and progression of HIV disease (28). After adjusting for the level of $\mathrm{CD}^{+}$ cells, high levels of $\mathrm{CD} 8^{+} \mathrm{CD} 38^{+}$cells were shown to constitute an additional poor prognostic sign (34).

The prognostic significance of numerous laboratory tests in HIV-infected children is similar to the situation in adults (1). Neonatally infected children who have early AIDS-related symptoms and poor survival (17) were more likely to have a low $\mathrm{CD}^{+}$count at the onset of symptoms than the other group of neonatally infected children (35). The striking prognostic relevance of the number of $\mathrm{CD}^{+}$cells in HIV infection of children is corroborated by the results of the present study. In addition, the present study demonstrated a significant correlation between the total number of $\mathrm{CD} 8$ cells and $\mathrm{CD} 8^{+} \mathrm{CD} 38^{+}$ cells and the survival of children with perinatal HrV infection who were less than $2 \mathrm{y}$ old at the time of entry into the study. Most of the young HIV-infected children who remained alive by the end of the study had a CD8 count of more than $750 / \mathrm{mm}^{3}$ and a $\mathrm{CD} 38^{+} \mathrm{CD} 8^{+}$count of more than $600 / \mathrm{mm}^{3}$ when first seen. Less than 2-y-old HIV-infected children who remained alive also were more likely to have a somewhat higher $\mathrm{CD}^{+} \mathrm{CD}^{+} 5 \mathrm{RO}^{+}$count at the time of study entry than those children who died. Among 2- to 12-y-old children no significant association between survival and initial $\mathrm{CD} 8$ and $\mathrm{CD} 8{ }^{+} \mathrm{CD} 38^{+}$counts was seen. The $\mathrm{CD} 8$ lymphocyte population plays a crucial role in the response of the host to HIV infection. $\mathrm{CD}^{+}$cells suppress the replication of HIV- 1 in $\mathrm{CD}^{+}$cells $(8,36)$, although with progression of HIV disease their anti-viral activity diminishes (37). The bad prognosis of HIV-infected adults with high levels of $\mathrm{CD} 38^{+} \mathrm{CD} 8^{+}$cells may be brought about by a number of mechanisms (34). $\mathrm{CD} 38^{+} \mathrm{CD} 8^{+}$cells may represent $\mathrm{CD} 8^{+}$cells with promiscuous cytotoxic activity that could lyse $\mathrm{CD} 4^{+}$cells and thereby accelerate the progression of HIV disease. Alternatively, the rise in the number of $\mathrm{CD} 38^{+} \mathrm{CD} 8^{+}$cells could reflect either a vigorous response of CD8 cells to an overwhelming viral load or a futile attempt to resist HIV infection by cells that have lost their anti-viral activity (36). Moreover, the expression of activation markers on $T$ cells may accompany their transition to a state of increased susceptibility to programmed cell death. Akbar et al. (38) showed that $\mathrm{CD}^{2} 5 \mathrm{RO}^{+} \mathrm{T}$ cells express reduced levels of bcl-2, and are more susceptible to apoptosis. Indeed, in HIV-infected individuals the augmented expression of activation markers on $\mathrm{CD}^{+}$cells is correlated with increased propensity for apoptotic death of $\mathrm{CD} 8^{+}$cells (39).

The finding that, unlike in the adult, low numbers of $\mathrm{CD} 8^{+}$ cells and $\mathrm{CD} 38^{+} \mathrm{CD} 8^{+}$cells are inversely related to the survival of HIV-infected children less than $2 y$ of age suggests that in young children a high number of these cells may be advantageous for mounting an early and effective response to HIV infection. Indeed, the possibility now arises that the relative resistance of children to the progression of HIV infection $(4,5)$ may in part reflect the fact that they have high numbers of $\mathrm{CD} 8$ cells expressing the CD38 activation marker even before HIV infection, so that they do not have to mobilize these cells.

\section{REFERENCES}

1. European Collaborative Study 1992 Risk factors for mother-to-child transmission of HIV-1. Lancet 339:1007-1012

2. Soeiro R, Rubinstein A, Rashbaum WK, Lyman DW 1992 Maternofetal transmission of AIDS: Frequency of HIV-1 nucleic acid sequences in human fetal DNA. J Infect Dis 166:707-709

3. Devash Y, Calvelli TA, Wood DG, Reagan KJ, Rubinstcin A 1990 Vertical transmission of human immunodeficiency virus is correlated with the absence of high affinity/avidity maternal antibodies to the gp120 principal neutralizing domain. Proc Natl Acad Sci USA 87:3445-3449

4. Goedert JJ, Kessler CM, Aledort LM, Biggar RJ, Andes WA, White GC 2d, Drummond JE, Vaidya K, Mann DL, Eyster ME, Ragni MV, Lederman MM, Cohen AR, Bray GL, Rosenberg PS, Friedman RM, Hilgartner MW, Blattner WA, Kroner B, Gail MH 1989 A prospective study of human immunodeficiency virus type 1 infection and the development of AIDS in subjects with hemophilia. $N$ Engl $J$ Med 321:1141-1148

5. Fletcher MA, Mosley JW, Hassett J, Gjerset GF, Kaplan J, Parker JW, Donegan E, Lusher JM, Lee H 1992 The Transfusion Safety Study Group. Effect of age on human immunodeficiency virus type 1-induced changes in lymphocyte populations among persons with congenital clotting disorders. Blood 80:831-840

6. Fahey JL, Taylor JMG, Detels R, Hofman B, Melmed R, Nishanian P, Giorgi JV 1990 The prognostic value of cellular and serologic markers in infection with human immunodeficiency virus type 1 . N Engl J Med 322:166-172

7. Prince HE, Kleinman S, Czaplicki C, John J, Williams AE 1990 Interrelationships between serologic markers of immune activation and $\mathrm{T}$ lymphocyte subsets in HIV infection. J Acquired Immune Defic Syndr 3:525-530

8. Levy JA 1993 Features of immunodeficiency virus infection and disease. Pediatr Res 33(suppl):S63-S69

9. Salazar-Gonzalez JF, Moody DJ, Giorgi JV, Martinez-Maza O, Mitsuyasu RT, Fahey JL 1985 Reduced ecto- $5^{\prime}$ nucleotidase activity and enhanced OKT10 and HLA-DR expression on CD8 ( $\Upsilon$ suppressor/cytotoxic) lymphocytes in the acquired immune deficiency syndrome: Evidence of CD8 cell immaturity. J Immunol 135:1778-1785

10. Yagi MJ, Joesten ME, Wallace J, Roboz JP, Bekesi JG 1991 Human immunodeficiency virus type 1 (HIV-1) genomic sequences and distinct changes in $\mathrm{CD} 8^{+}$ lymphocytes precede detectable levels of HIV-1 antibodies in high-risk homosexuaIs. J Infect Dis 164:183-188

11. Yagi MJ, Chu F-N, Jiang JD, Wallace J, Mason P, Liu Y, Carafa J, Bekesi JG 1992 Increases in soluble $\mathrm{CD} 8$ antigen in plasma, and $\mathrm{CD} 8^{+}$and $\mathrm{CD} 8^{+} \mathrm{CD} 38^{+}$cells in human immunodeficiency virus type-1 infection. Clin Immunol Immunopathol $63: 126-134$ 
12. Prince HE, Jensen ER 1991 Three-color cytofluorometric analysis of CD8 cell subsets in HIV infection. J Acquired Immune Defic Syndr 4:1227-1232

13. Janossy G, Jiang JD, Roboz JP, Bofill M, Bekesi JG 1992 Activated CD45RO, CD8 $T$ lymphocytes in HIV-1 infection In: Janossy G, Autran B, Miedema F (eds) Immunodeficiency in HIV infection and AIDS. Workshop on Immunodeficiency in HIV-1 Infections. Karger, Bascl, pp 195-210

14. Akbar AN, Terry L, Timms A, Beverly PCL, Janossy G 1988 Loss of CD45R and gain of UCHL1 reactivity is a feature of primed T cells. J Immunol 40:2171-2178

15. Sanders ME, Makgoba MW, Shaw S 1988 Human naive and memory cells: Reinterpretation and further characterization of helper-inducer and suppressor-inducer subsets. Immunol Today 9:195-199

16. Morimoto C, Letvin NL, Boyd AW, Hagman M, Brown HM, Korncli MH, Schlossman SF 1985 The isolation and characterization of the human suppressor-inducer subset. J Inmunol 134:3762-3769

17. Blanche S, Tardieu M, Duliege AM, Rouzioux C, Le Deist F, Fukunaga K, Canglia M, Jacomet C, Messiah A, Griscelli C 1990 Longitudinal study of 94 HIV symptomatic infants with perinatally acquired human immunodeficiency virus infection: evidence for a bimodal expression of clinical and biological symptoms. Am J Dis Child 144:1210-1215

18. Frocbel KS, Doherty KV, Whitelaw JA, Hague RA, Mok JY, Bird AG 1991 Increased expression of the CD45RO (memory) antigen on T cells in HIV-infected children. AIDS 5:97-99

19. Placger-Marshall S, Hultin P, Bertolli J, O'Rourke S, Kobayashi R, Kobayashi AL, Giorgi JV, Bryson Y, Stichm ER 1993 Activation and differentiation antigens in T cells of healthy, at-risk, and HIV-infected children. J Acquired Immune Defic Syndr 6:984-993

20. Calvelli T, Denny T N, Paxton H, Gelman R, Kagan J 1993 Guideline for flow cytometric immunophenotyping: A report from the National Institute of Allergy and Infectious Diseases, Division of AIDS. Cytometry 14:702-715

21. McKinney RE, Wilfert CM 1992 Lymphocyte subsets in children younger than 2 years old: Normal values in a population at risk for human immunodeficiency virus infection and diagnostic and prognostic application to infected children. Pediatr Infect Dis J 11:639-644

22. Bofill M, Janossy G, Lec CA, MacDonald-Burns D, Phillips AN, Sabin C, Timms A, Johnson MA, Kernoff PBA 1992 Laboratory control values for CD4 and CD8 T lymphocytes. Implications for HIV-1 diagnosis. Clin Exp Immunol 88:243-252

23. Denny T, Yogev R, Gelman R, Skuza C, Oleske J, Chadwick E, Cheng S-C, Connor E 1992 Lymphocyte subsets in healthy children during the first 5 years of life. JAMA 267:1484-1488

24. Erkeller-Yuksel FM, Dencys V, Yuksel B, Hannet l, Hulstacrt F, Hamilton C, Mackinnon H, Stokes LT, Munhyeshui V, Valangendonck F, De Bruyere M, Bach BA, Lydyard PM 1992 Age-related changes in human blood lymphocyte subpopulations. J Pediatr 120:216-222

25. The European Collaborative Study 1992 Age-related standards for T lymphocyte subsets based on uninfected children born to human immunodeficiency virus 1-infected women. Pediatr Infect Dis J 11:1018 -1026
26. Malavasi F, Funaro A, Roggero S, Horenstcin A, Calosso L, Mehta K 1994 Human CD38: A glycoprotein in search of a function. Immunol Today 15:95-97

27. Kestens L, Vanham G, Gigase P, Young G, Hannet I, Vanlangendonck F, Hulstaert F, Bach BA 1992 Expression of activation antigens, HLA-DR and CD38, on CD8 lymphocytes during HIV-1 infection. AIDS 6:793-797

28. Levacher M, Hustaert F, Tallet S, Ullery S, Pocidalo JJ, Bach BA 1992 The significance of activation markers on CD8 lymphocytes in human immunodeficiency syndrome: staging and prognostic value. Clin Exp Immunol 90:376-382

29. Hayward LA, Lee J, Beverley PCL 1989 Ontogeny of expression of UCHL1 antigen on TCR-1 ${ }^{+}(\mathrm{CD} 4 / 8)$ and TcR $\delta^{++}$T cells. Eur J Immunol 19:771-773

30. Janossy G, Tidman N, Papageorgiou ES, Kung PC, Goldstein G 1981 Distribution of $\mathrm{T}$ lymphocyte subsets in the human bone marrow and thymus: An analysis with monoclonal antibodies. J Immunnol 126:1608-1613

31. Prince HE, York J, Jensen ER 1992 Phenotypic comparison of the three populations of human lymphocytes defined by CD45RO and CD45RA expression. Cell Immuno $145: 254-262$

32. Vanham G, Kestens L, Penne G, Goilav C, Gigase P, Vandenbruaene M, Goeman J, van der Grocn G, Ceuppens JL 1991 Subset markers of CD8 $8^{+}$cells and their relation to enhanced cytotoxic activity during human immunodeficiency virus infection. $J$ Clin Immunol 11:345-356

33. Ho H-N, Hultin LE, Mitsuyasu RT, Matud JL, Hausner MA, Bockstoce D, Chou CC, Orourke S, Taylor JMG, Giorgi JV 1993 Circulating HIV-specific CD8 ${ }^{+}$cytotoxic T-cells express CD38 and HLA-DR antigens. J Immunol 150:3070-3079

34. Giorgi JV, Liu ZL, Hultin LE, Cumberland WG, Hennessey K, Detels R, from the Los Angeles Center Multicenter AIDS Cohort Study 1993 Elevated levels of $\mathrm{CD} 38^{+} \mathrm{CD} 8^{+} \mathrm{T}$ cells in HIV infection add to the prognostic value of low $\mathrm{CD} 4^{+} \mathrm{T}$ cell levels. Results of 6 years of follow up. J Acquired Immune Defic Syndr 6:904-912

35. Duliege A-M, Messiah A, Blanche S, Tardicu M, Griscelli C, Spira A 1992 Natural history of immunodeficiency virus type 1 infection in children: Prognostic value of laboratory tests on the bimodal progression of the disease. Pediatr Infect Dis J $11: 630-635$

36. Wiviott LD, Walker CM, Levy JA $1990 \mathrm{CD} 8^{+}$lymphocytes suppress HIV production by autologous $\mathrm{CD}^{+}$cclls without climinating the infected cells from the culture. Cell Immunol 128:628-634

37. Mackewicz CE, Ortega HW, Levy JA 1991 CD8 ${ }^{+}$cell anti-HIV activity correlates with the clinical state of the infected individual. J Clin Invest 87:1462-1466

38. Akbar AN, Borthwick N, Salmon M, Gombert W, Bofil M, Shamsadecn N, Pilling D, Pett S, Grundy JE, Janossy G 1993 The significance of low bcl-2 expression by CD45RO $\mathrm{T}$ cells in normal individuals and patients with acute viral infections. The role of apoptosis in T cell memory. J Exp Med 178:427-438

39. Lewis DE, Tang DSN, Adu-Oppong A, Schober W., Rodgers JR 1994 Anergy and apoptosis in $\mathrm{CD}^{+.} \mathrm{T}$ cells from HIV-infected persons. J Immunol 153:412-420 